\title{
ANTENNAL MORPHOLOGY AND SENSILLA OF THE PREDACEOUS LADYBIRDS, MENOCHILUS SEXMACULATUS AND PROPYLEA DISSECTA
}

\author{
AHMAD PERVEZ ${ }^{1}$, MEENA YADAV $2, *$, and HAKAN BOZDOGAN³ \\ ${ }^{1}$ Biocontrol Laboratory, Department of Zoology, Radhey Hari Govt. P.G. College, Kashipur, Udham Singh Nagar - 244713, \\ Uttarakhand, India \\ ${ }^{2}$ Department of Zoology, Maitreyi College, University of Delhi, New Delhi - 110021, India \\ ${ }^{3}$ Ahi Evran University, Vocation School of Technical Sciences, Department of Plant and Animal Production, 40100, Kırşehir, Turkey \\ *Corresponding author: ahmadpervez@yahoo.com
}

\section{ABSTRACT}

Menochilus sexmaculatus and Propylea dissecta (Coleoptera: Coccinellidae) are predaceous ladybird beetles with immense biological control potential. The morphology of the antennae of the adults along with the diversity and distribution of sensilla were investigated using a scanning electron microscope as they are the main sensory organs involved in chemical communication, thermo-reception, materecognition, gustation, etc. The antennae of males and females in both species were clavate and consisted of three parts: scape, pedicel and a 9-segmented flagellum. The antennae of male and female $P$. dissecta were significantly longer than those of $M$. sexmaculatus despite their overall body size being smaller, probably due to the much longer F9 flagellomere in P. dissecta. Antennae of female ladybirds of both species exhibited sexual dimorphism in being longer than those of males. Scape was longer than other antennal parts in both species of ladybirds. There was a great diversity of sensilla with most of them on the ninth-flagellomere. We identified nine types of sensillum: chaetica, trichoidea, basiconica, Böhm bristles, campaniformia, placoidea, coeloconica, sporangia and styloconica. Coeloconica were restricted to flagellomere F8 in male $P$. dissecta and female $M$. sexmaculatus, respectively, indicating sexual dimorphism and male-related functions of this sensillum.

Keywords: antenna; aphid; Coccinellidae; ladybird; morphology; sensilla

\section{Introduction}

Majority of predaceous ladybirds (Coleoptera: Coccinellidae) can be utilized for the biological control of numerous phytophagous insect-pests: aphids, scale-insects, mealybugs and whiteflies (Hodek et al. 2012; Omkar and Pervez 2016) infesting several economically important crops (Pervez et al. 2020). The optimization of their predation potential (Pervez and Yadav 2018; Pervez et al. 2018), prey consumption (Pervez and Kumar 2017) and mating behaviour (Pervez and Singh 2013) may enhance the biocontrol potential of ladybirds.

Menochilus sexmaculatus (Fabricius) is an Oriental generalist aphidophagous ladybird, which occurs abundantly in agricultural and horticultural fields on the Indian subcontinent (Poorani 2002; Omkar and Pervez 2004). Its reproductive and mating behaviour was recently studied by Chaudhary et al. (2016) and Dubey et al. (2018). Similarly, Propylea dissecta (Mulsant) is also an important Oriental aphidophagous ladybird (Omkar and Pervez 2011) with marked sexual dimorphism (Omkar and Pervez 2000), which have facilitated mating studies on this species (Pervez et al. 2004; Omkar and Pervez 2005). These species of ladybirds coexist in most agro-ecosystems. Scanning electron microscopy of the antennal sensilla may help in achieving a better understanding of the ecological interactions between prey-predator and predators sharing a common prey resource. It may also help in behavioural studies on mate-recognition, courtship and mating. Evidence indicates that adult males use their antennae to examine females, which may indicate that antennae are important in mate recognition (Srivastava and Omkar 2003; Omkar and Pervez 2005). In addition, there is a marked sexual dimorphism in the shape and size of their antennae and diversity of antennal sensilla (Jourdan et al. 1995; Srivastava and Omkar 2003; Omkar and Pervez 2008). Therefore, a scanning electron microscopy study of the antennal sensilla of two aphidophagous ladybirds, M. sexmaculatus and $P$. dissecta, was carried out in order to (i) determine the morphological differences in the male and female antennal sensilla (ii) identify the sensilla on the terminal segments that are involved in mate-recognition, and (iii) to identify the similarities and differences in the types and distribution of antennal sensilla in these two similar-sized, polymorphic and co-existing species of ladybird.

\section{Materials and Methods}

\section{Insect culture}

We collected adults of M. sexmaculatus and P. dissecta from agricultural fields near the city of Kashipur, India $\left(29^{\circ} 2104^{\prime} \mathrm{N}, 78^{\circ} 9619^{\prime} \mathrm{E}\right)$ and in the laboratory they were sexually identified based on their genitalia viewed under a stereoscopic trinocular (Lyzer) at $40 \times$ and $100 \times$ magnifications, which was connected to a personal computer (DELL). Conspecific male and female beetles were paired in plastic Petri dishes $(9.0 \mathrm{~cm}$ diameter $\times 2.0 \mathrm{~cm}$ deep) containing an ad libitum supply of the aphid Aphis craccivora (Koch) as food. Then, these Petri dishes were kept under constant conditions $\left(27 \pm 2{ }^{\circ} \mathrm{C} ; 65 \pm 5 \% \mathrm{RH}\right.$; 

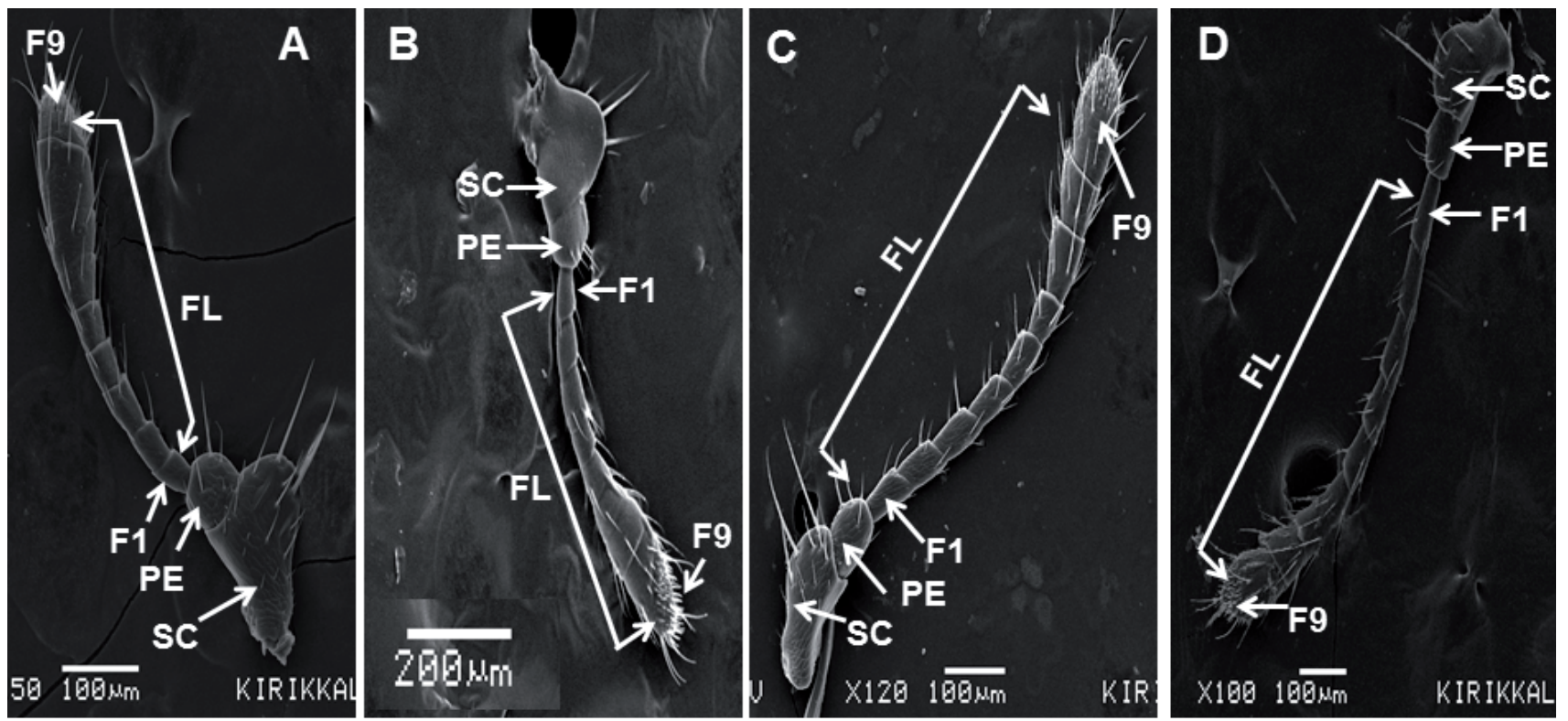

Fig. 1 Antennae of P. dissecta and M. sexmaculatus. A. Male (M. sexmaculatus P. dissecta); B. Female (M. sexmaculatus); C. Male (P. dissecta); D. Female (P. dissecta). SC - scape; PE - pedicel; F1-F9 - flagellomeres; FL - flagellum.

14L:10D) in an Environmental Test Chamber (REMI, Remi Instruments). The adults mated and the females laid eggs in clusters, which were collected daily and stored at the above temperature for experimental purpose. The larvae that hatched from these eggs were reared to the adult stage (space and food as above), which were then isolated in Petri dishes and kept for 10 days before being used in the following studies (space and food as above).

\section{Scanning electron microscopy}

Antennectomy of freshly anaesthetized 10-day-old adult male and female $M$. sexmaculatus and $P$. dissecta was carried out under a Stereomicroscope (Lieca S8APO). The antennae were carefully excised using a micro-blade and then immersed in $10 \% \mathrm{KOH}$ for 1 hour to remove unwanted tissues. The processed antennae were dehydrated in a graded series of ethanol (50\%, 70\%, 90\% and $100 \%)$ for 10 minutes, air-dried for 30 minutes at $30{ }^{\circ} \mathrm{C}$ and coated with a thin layer of gold using a Polaron SC 502 sputter coater. Then, each antenna was mounted singly on a stub, using double-sided sticky tape and coated with gold-palladium. The stubs with the antennae were individually inserted into a scanning electron microscope (Jeol JSM 5600) and the morphological details recorded at different magnifications at $15 \mathrm{kV}$. This was replicated six times $(\mathrm{n}=6)$.

\section{Statistical analyses}

The lengths of antennae and their different components for both the sexes were compared using a two-sample t-test and statistical software, SAS 9.0 (2002). The lengths of the antennal components were subjected to a two-way ANOVA using 'species' and 'sex' as independent variables and length of the different antennal components, viz. 'scape', 'pedicel', 'flagellum' and 'total length of antenna' as dependent variables using statistical software, SAS 9.0 (2002). Means were compared using
Tukey's HSD Test and SAS 9.0 (2002). Various sensilla were compared at the 'species' and 'gender' levels using 't' tests (SAS 9.0).

\section{Results}

Antennae of the ladybirds, M. sexmaculatus and P. dissecta are located in front of their compound eyes. Each antenna consists of a scape, pedicel and flagellum consisting of nine flagellomeres (F1-F9) (Fig. 1).

\section{Morphology of the antennae of $M$. sexmaculatus}

The scape of the antenna of adult males $(200.17 \pm 5.31$ $\mu \mathrm{m})$ is significantly $(t=17.08 ; \mathrm{P}<0.0001 ; \mathrm{d}$. $\mathrm{f} .=1,10)$ longer than that of females $(150.00 \pm 4.86 \mu \mathrm{m})$. The proximal and middle part of the scape is broader in the female and the distal part significantly broader in the male (Fig. 1A, B; Table 1). In females the pedicel of an antenna is longer $(80.17 \pm 2.86 \mu \mathrm{m})$ than that of males $(60.00$ $\pm 3.41 \mu \mathrm{m})$. In males, however, the pedicel is significantly broader in the distal region than in females (Table 1 ). The first flagellomere, $F 1,(t=-29.51 ; \mathrm{P}<0.0001 ; \mathrm{d}$. $\mathrm{f}$. $=1,10), F 2(t=-21.20 ; \mathrm{P}<0.0001 ; \mathrm{d}$. f. $=1,10), F 3(t=$ -9.64; $\mathrm{P}<0.0001$; d. f. $=1,10)$ and $F 9(t=-3.39 ; \mathrm{P}<0.01$; d. f. $=1,10)$ are significantly shorter, and $F 8$ significantly longer $(t=11.81 ; \mathrm{P}<0.0001 ; \mathrm{d}$. $\mathrm{f} .=1,10)$ in adult males than in females. The other flagellomeres (F4 to $F 7$ ) are similar in size in both sexes (Table 1; N.S.). The overall lengths of the flagellum $(t=-11.45 ; \mathrm{P}<0.0001 ; \mathrm{d}$. f. $=1$, $10)$ and an antenna $(t=-6.85 ; \mathrm{P}<0.0001 ; \mathrm{d}$. f. $=1,10)$ are significantly shorter in adult males than females.

\section{Morphology of the antennae of $P$. dissecta}

The scape $(t=-2.91 ; \mathrm{P}<0.05 ; \mathrm{d}$. f. $=1,10)$, pedicel $(t=$ -4.09 ; P $<0.01$; d. f. $=1,10)$, F5 $(t=-2.54 ; \mathrm{P}<0.05$; d. f. 
Table 1 Lengths and widths of antennal segments of adult male and female M. sexmaculatus.

\begin{tabular}{|c|c|c|c|c|c|c|c|}
\hline \multirow{3}{*}{$\begin{array}{l}\text { Menochilus } \\
\text { sexmaculatus }\end{array}$} & \multicolumn{3}{|c|}{ Male } & \multicolumn{3}{|c|}{ Female } & \multirow[t]{3}{*}{ T-test* } \\
\hline & \multirow[t]{2}{*}{ Length $(\mu \mathrm{m})$} & \multicolumn{2}{|c|}{ Width $(\mu \mathrm{m})$} & \multirow{2}{*}{ Length $(\mu \mathrm{m})$} & \multicolumn{2}{|c|}{ Width $(\mu \mathrm{m})$} & \\
\hline & & Proximal & Distal & & Proximal & Distal & \\
\hline Scape & $200.17 \pm 5.31$ & $57.5 \pm 1.51$ & $\begin{array}{r}125.0 \\
\pm 5.20\end{array}$ & $150.00 \pm 4.86$ & $150.0 \pm 4.52$ & $80.0 \pm 2.25$ & $\begin{array}{l}t=17.08 \\
P<0.0001\end{array}$ \\
\hline Pedicel & $60.00 \pm 3.41$ & $77.5 \pm 2.50$ & $70.0 \pm 3.25$ & $80.17 \pm 2.86$ & $75.0 \pm 3.12$ & $55.0 \pm 3.25$ & $\begin{array}{l}t=-11.11 \\
P<0.0001\end{array}$ \\
\hline F1 & $40.00 \pm 3.22$ & $30.0 \pm 1.56$ & $40.0 \pm 1.76$ & $95.17 \pm 3.25$ & $25.0 \pm 1.25$ & $35.0 \pm 2.45$ & $\begin{array}{l}t=-29.51 \\
P<0.0001\end{array}$ \\
\hline F2 & $50.00 \pm 3.85$ & $32.5 \pm 1.95$ & $35.0 \pm 3.12$ & $96.33 \pm 3.72$ & $35.0 \pm 2.10$ & $40.0 \pm 2.20$ & $\begin{array}{l}t=-21.20 \\
P<0.0001\end{array}$ \\
\hline F3 & $57.50 \pm 4.59$ & $25.0 \pm 2.15$ & $35.0 \pm 3.45$ & $80.00 \pm 3.41$ & $45.0 \pm 2.30$ & $40.0 \pm 2.55$ & $\begin{array}{l}t=-9.64 ; \\
P<0.0001\end{array}$ \\
\hline F4 & $50.17 \pm 3.31$ & $27.5 \pm 3.10$ & $35.0 \pm 3.15$ & $50.00 \pm 3.16$ & $40.0 \pm 2.50$ & $45.0 \pm 2.40$ & $\begin{array}{c}t=0.06 \\
\text { N.S. }\end{array}$ \\
\hline F5 & $50.17 \pm 3.31$ & $30.0 \pm 1.50$ & $40.0 \pm 2.20$ & $50.00 \pm 5.10$ & $40.0 \pm 2.25$ & $55.0 \pm 2.80$ & $\begin{array}{c}t=0.14 \\
\text { N.S. }\end{array}$ \\
\hline F6 & $50.00 \pm 3.85$ & $32.5 \pm 2.25$ & $52.5 \pm 3.50$ & $49.17 \pm 3.31$ & $50.0 \pm 2.30$ & $80.0 \pm 2.90$ & $\begin{array}{c}t=0.37 \\
\text { N.S. }\end{array}$ \\
\hline F7 & $50.00 \pm 3.41$ & $55.0 \pm 3.40$ & $65.0 \pm 3.35$ & $50.83 \pm 3.39$ & $80.0 \pm 2.85$ & $90.0 \pm 2.70$ & $\mathrm{t}=-0.40 ;$ N.S. \\
\hline F8 & $80.00 \pm 3.41$ & $65.0 \pm 1.52$ & $65.0 \pm 2.25$ & $50.33 \pm 5.13$ & $87.5 \pm 2.75$ & $90.0 \pm 3.30$ & $\begin{array}{c}t=11.81 ; \\
P<0.0001\end{array}$ \\
\hline F9 & $52.50 \pm 4.93$ & $65.0 \pm 3.25$ & $35.0 \pm 2.54$ & $62.50 \pm 5.28$ & $102.5 \pm 2.95$ & $37.5 \pm 2.80$ & $\begin{array}{c}t=-3.39 \\
P<0.01\end{array}$ \\
\hline $\begin{array}{l}\text { Flagellum } \\
\text { length }\end{array}$ & $480.30 \pm 16.60$ & & & $584.50 \pm 14.8$ & & & $\begin{array}{l}t=-11.45 \\
P<0.0001\end{array}$ \\
\hline $\begin{array}{l}\text { Total length } \\
\text { of antenna }\end{array}$ & $740.50 \pm 18.60$ & & & $814.70 \pm 18.9$ & & & $\begin{array}{l}t=-6.85 \\
P<0.0001\end{array}$ \\
\hline
\end{tabular}

The data are means \pm S.D.

* Only the lengths of antennal components of adult male and female, M. sexmaculatus were subjected to t-tests.

$=1,10)$ and $F 6(t=-4.45 ; \mathrm{P}<0.05 ; \mathrm{d} . \mathrm{f} .=1,10)$ of adult males are significantly shorter than those of adult females (Fig. 1C, D; Table 2). The flagellomeres are significantly broader in females than in males. The total lengths of the flagellum $(719.50 \pm 22.40 \mu \mathrm{m}$ in male and $752.20 \pm$ $16.40 \mu \mathrm{m}$ in female) and an antenna (1000.30 $\pm 21.60 \mu \mathrm{m}$ in male and $1055.50 \pm 22.00 \mu \mathrm{m}$ in females) are greater in females than in males.

Sensilla occurred mainly on F9 flagellomere in adult males and females in both species. Two-way ANOVA revealed significant effects of 'sex' $(F=70.80 ; \mathrm{P}<0.0001$; . $\mathrm{f} .=1)$, 'species' $(F=473.62 ; \mathrm{P}<0.0001 ;$ d. f. $=1)$ and in the interaction between 'sex' and 'species' ( $F=167.92 ; \mathrm{P}$ $<0.0001$; d. f. $=1)$ on the length of the 'scape' and significant effects of 'sex' $(F=87.86 ; \mathrm{P}<0.0001 ;$ d. f. $=1)$, 'spe$\operatorname{cies}^{\prime}(F=5.96 ; \mathrm{P}<0.05 ;$ d. f. $=1)$ and 'interaction' ( $\operatorname{sex} \mathrm{x}$ species; $F=5.96 ; \mathrm{P}<0.05 ; \mathrm{d}$. f. $=1)$ on the length of the 'pedicel'. Similarly, 'sex' $(F=88.31 ; \mathrm{P}<0.0001$; d. f. $=1)$, 'species' $(F=783.21 ; \mathrm{P}<0.0001 ; \mathrm{d}$. $\mathrm{f} .=1)$ and 'interaction' (sex x species; $F=24.06 ; \mathrm{P}<0.0001 ; \mathrm{d}$. f. $=1$ ) had a significant effect on the length of the pedicel. This cumulatively resulted in significant effects of 'sex' $(F=$ 60.41; $\mathrm{P}<0.0001$; d. $\mathrm{f} .=1)$, 'species' $(F=908.18 ; \mathrm{P}<$ 0.0001 ; d. f. $=1$ ) on the total length of an antenna. The 'interaction' between 'sex' and 'species', however was not statistically significant $(F=5.96$; $\mathrm{P}<0.05 ; \mathrm{d}$. f. $=1)$ for the total length of an antenna.

\section{Types and distribution of sensilla on the antennae of $M$. sexmaculatus and $P$. dissecta}

The scanning electron microscopy revealed nine types of sensilla in the two species of ladybird studied: sensilla chaetica ( $\mathrm{Sc} 1-\mathrm{Sc} 4)$, sensilla trichoidea $(\operatorname{Tr} 1-\operatorname{Tr} 4)$, sensilla basiconica (Ba1-Ba3), Böhm bristles (BB), sensilla campaniformia (Ca), sensilla coeloconica (Co), sensilla styloconica (St), sensilla sporangia (Sp) and sensilla placoidea $(\mathrm{Pl})$. Based on their lengths, these sensilla can be arranged in a descending order: $\mathrm{Sc}>\mathrm{Tr}>\mathrm{Ba}>\mathrm{BB}>\mathrm{St}>\mathrm{Ca}>\mathrm{Pl}$.

\section{Sensilla chaetica (Sc)}

Sensillum chaetica is the longest type of sensilla present on the antennae of male and female ladybirds. There are four subtypes of sensilla chaetica $(\mathrm{Scl}-\mathrm{Sc} 4) . \mathrm{Scl}$ is the longest, with a straight sensillum, which has grooved cuticular walls and a pointed tip. Sc2 is shorter than Sc1 with a blunt tip. It is present on the antenna at an angle of $50-70^{\circ}$ to the antennal axis. Sc3 is straight with a slightly curved tip. Sc4 is the smallest of those with 
Table 2 Lengths and widths of antennal segments of adult male and female P. dissecta.

\begin{tabular}{|c|c|c|c|c|c|c|c|}
\hline \multirow{3}{*}{$\begin{array}{l}\text { Propylea } \\
\text { dissecta }\end{array}$} & \multicolumn{3}{|c|}{ Male } & \multicolumn{3}{|c|}{ Female } & \multirow[t]{3}{*}{ T-test } \\
\hline & \multirow[t]{2}{*}{ Length $(\mu \mathrm{m})$} & \multicolumn{2}{|c|}{ Width ( $\mu \mathrm{m})$} & \multirow[t]{2}{*}{ Length $(\mu \mathrm{m})$} & \multicolumn{2}{|c|}{ Width $(\mu \mathrm{m})$} & \\
\hline & & Proximal & Distal & & Proximal & Distal & \\
\hline Scape & $220.83 \pm 4.92$ & $60.0 \pm 3.15$ & $\begin{array}{c}100.0 \pm \\
4.25\end{array}$ & $231.50 \pm 7.50$ & $\begin{array}{c}102.56 \\
\pm 3.65\end{array}$ & $107.69 \pm 4.50$ & $\begin{array}{c}t=-2.91 \\
P<0.05\end{array}$ \\
\hline Pedicel & $60.00 \pm 5.83$ & $55.0 \pm 2.15$ & $55.0 \pm 3.75$ & $71.83 \pm 4.02$ & $76.9 \pm 3.20$ & $71.79 \pm 3.50$ & $\begin{array}{c}t=-4.09 \\
P<0.01\end{array}$ \\
\hline F1 & $70.33 \pm 4.55$ & $40.0 \pm 2.15$ & $45.0 \pm 2.35$ & $71.83 \pm 3.13$ & $46.15 \pm 2.30$ & $56.0 \pm 1.25$ & $t=-0.69 ;$ N.S. \\
\hline F2 & $65.00 \pm 4.20$ & $40.0 \pm 1.65$ & $45.0 \pm 1.80$ & $58.33 \pm 8.16$ & $56.41 \pm 1.85$ & $56.0 \pm 1.45$ & $\mathrm{t}=1.78 ;$ N.S. \\
\hline F3 & $74.17 \pm 3.82$ & $40.0 \pm 1.95$ & $45.0 \pm 1.25$ & $72.17 \pm 4.17$ & $51.28 \pm 1.85$ & $46.15 \pm 1.70$ & $t=0.87 ;$ N.S. \\
\hline F4 & $70.00 \pm 6.03$ & $40.0 \pm 1.45$ & $45.0 \pm 1.65$ & $66.33 \pm 2.16$ & $41.02 \pm 1.90$ & $51.28 \pm 1.45$ & $t=1.40 ;$ N.S. \\
\hline F5 & $74.33 \pm 5.89$ & $35.0 \pm 1.15$ & $40.0 \pm 1.20$ & $82.50 \pm 5.24$ & $41.02 \pm 1.65$ & $46.15 \pm 1.75$ & $\begin{array}{c}t=-2.54 \\
P<0.05\end{array}$ \\
\hline F6 & $60.50 \pm 4.37$ & $30.0 \pm 1.25$ & $35.0 \pm 1.60$ & $71.83 \pm 4.45$ & $35.90 \pm 1.50$ & $46.15 \pm 1.55$ & $\begin{array}{l}t=-4.45 \\
P<0.001\end{array}$ \\
\hline F7 & $90.00 \pm 4.47$ & $30.0 \pm 1.60$ & $55.0 \pm 1.85$ & $92.33 \pm 5.57$ & $41.02 \pm 2.15$ & $66.66 \pm 2.25$ & $t=-0.80 ;$ N.S. \\
\hline F8 & $50.17 \pm 5.31$ & $40.0 \pm 2.15$ & $65.0 \pm 2.55$ & $87.17 \pm 6.59$ & $\begin{array}{l}66.66 \\
\pm 2.40\end{array}$ & $87.0 \pm 2.65$ & $\begin{array}{l}t=-10.52 \\
P<0.0001\end{array}$ \\
\hline F9 & $165.00 \pm 9.49$ & $55.0 \pm 2.65$ & $45.0 \pm 1.75$ & $149.67 \pm 4.89$ & $\begin{array}{l}87.18 \\
\pm 2.95\end{array}$ & $92.3 \pm 3.15$ & $\begin{array}{l}t=3.52 \\
P<0.01\end{array}$ \\
\hline $\begin{array}{l}\text { Flagellum } \\
\text { length }\end{array}$ & $719.50 \pm 22.40$ & & & $752.20 \pm 16.40$ & & & $\begin{array}{c}t=-2.88 \\
P<0.05\end{array}$ \\
\hline $\begin{array}{l}\text { Total length } \\
\text { of antenna }\end{array}$ & $1000.30 \pm 21.60$ & & & $1055.50 \pm 22.00$ & & & $\begin{array}{l}t=-4.37 \\
P<0.001\end{array}$ \\
\hline
\end{tabular}

The data are means \pm S.D.

* Only the lengths of antennal components of adult male and female, M. sexmaculatus were subjected to t-tests.

a pointed tip. These sensilla occur mostly on the scape and ninth flagellomere (F9) of the antennae of adult males and females.

In $M$. sexmaculatus, three Sc1 $(120-135 \mu \mathrm{m})$, two Sc2 $(70-90 \mu \mathrm{m})$, five Sc3 $(40-55 \mu \mathrm{m})$ and three Sc4 $(10-20 \mu \mathrm{m})$ are present on the scape of males and three Sc1 $(55-65 \mu \mathrm{m})$ and two Sc2 $(20-30 \mu \mathrm{m})$ on those of females (Fig. 2). Two Sc2 and four Sc3 are present on the pedicel of males. Four Sc2 and two Sc4 are present on the pedicel of females (Fig. 2). On the flagellomeres, four and seven Sc1 $(75-90 \mu \mathrm{m})$ are present on $F 8$ and $F 9$, respectively, and three Sc3 $(50-80 \mu \mathrm{m})$ on $F 8$ of male antennae. The females have five Sc1 $(55-65 \mu \mathrm{m})$ and eight Sc2 $(70-80 \mu \mathrm{m})$ on F9 and three Sc1 (55-65 $\mu \mathrm{m})$ on F8 (Fig. 3).

There are three subtypes of sensilla chaetica: Sc1, Sc2 and Sc4, on the scape and pedicel of adult males of $P$. dissecta. There are two Sc1 $(115-193 \mu \mathrm{m})$, one Sc2 $(83-103 \mu \mathrm{m})$, three Sc3 $(50-57 \mu \mathrm{m})$ and six Sc4 $(26-$ $53 \mu \mathrm{m})$ sensilla on the scape in males (Fig. 4A1) and one Sc1 $(140 \mu \mathrm{m})$, three Sc2 $(60-70 \mu \mathrm{m})$, four Sc3 $(50-60 \mu \mathrm{m})$ and six Sc4 $(26-30 \mu \mathrm{m})$ on the scape in females (Fig. 4A2). In addition, there are two Sc2, one Sc3 and two Sc4 sensilla on the pedicel in males and two each of Sc2, Sc3 and Sc4 in females (Fig. 4A1, A2). On male F8 flagellomere there are three Sc1and two Sc2 and Sc3, and on F9 seven Sc1, three Sc2 and two Sc3 (Fig. 4B1). The Sc1 and Sc2 sensilla on F9 of females were signifi- cantly shorter in length than those on males $(t=-4.57$; $\mathrm{P}$ $<0.0001$; d.f. $=9$ ).

\section{Sensilla trichoidea (Tr)}

Trichoidea are more slender and the second-longest sensillum and are present on F9 flagellomere in both of the species and on the scape of female M. sexmaculatus. There are three subtypes of sensilla trichoidea ( $\operatorname{Tr} 1-\operatorname{Tr} 3)$. $\operatorname{Tr} 1$ has a pointed tip, $\operatorname{Tr} 2$ and $\operatorname{Tr} 3$ are shorter with pointed tip tapering from base to tip. In M. sexmaculatus, three subtypes of trichoidea $(\operatorname{Tr} 1, \operatorname{Tr} 2$ and $\operatorname{Tr} 3)$ are present on the scape of females. There are two $\operatorname{Tr} 1$ and numerous $\operatorname{Tr} 2$ on $F 9$ of males and 6-7 Tr1 and numerous $\operatorname{Tr} 3$ on that of females (Fig. 3). In P. dissecta, there are eight $\operatorname{Tr} 1$ $(30-35 \mu \mathrm{m})$, two $\operatorname{Tr} 2(10-20 \mu \mathrm{m})$ and several $\operatorname{Tr} 3(6-12)$ on flagellomere $F 9$ of males (Fig. 4B1) and four $\operatorname{Tr} 1$ $(20-25 \mu \mathrm{m})$, one $\operatorname{Tr} 2(10-20 \mu \mathrm{m})$ and one $\operatorname{Tr} 3(4-6 \mu \mathrm{m})$ on that of females (Fig. 4B2).

\section{Sensilla basiconica ( $\mathrm{Ba}$ )}

Sensilla basiconica are blunt tipped, slightly curved and stout pegs. There are three subtypes of $\mathrm{Ba}: \mathrm{Ba} 1, \mathrm{Ba} 2$ and $\mathrm{B} 3$. $\mathrm{Ba} 1$ is the shortest and resembles $\mathrm{Ba} 2$ in having a blunt tip. $\mathrm{Ba} 3$ is longer than $\mathrm{Ba} 1$ and $\mathrm{Ba} 2$ with a pointed tip and only occurs on F9. In M. sexmaculatus there is one Bal sensilla on the scape (Fig. 2) and two Bal (6-9 $\mu \mathrm{m})$, numerous Ba2 $(8-13 \mu \mathrm{m})$ and $\mathrm{Ba} 3(12-15 \mu \mathrm{m})$ on apical region 


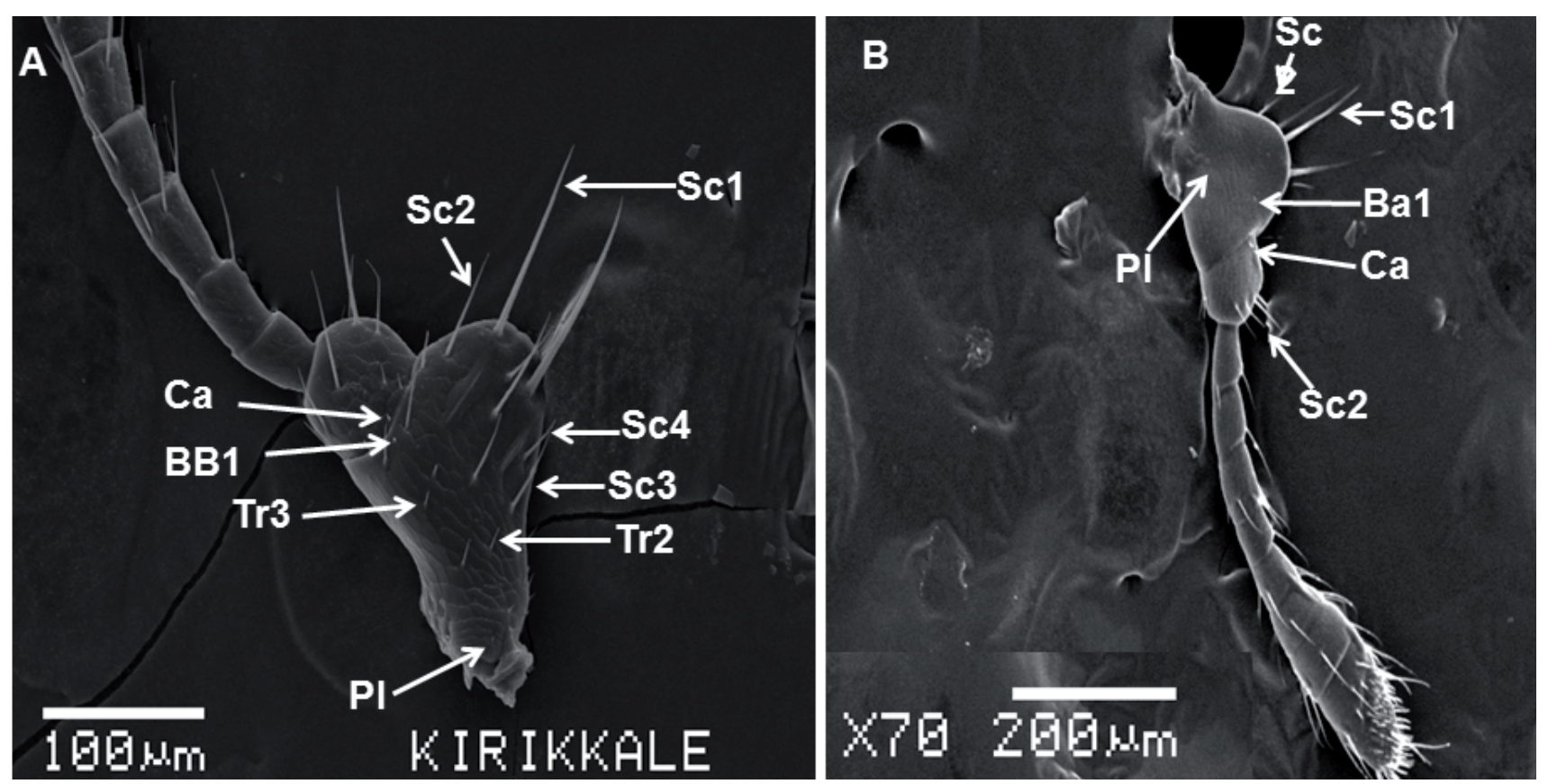

Fig. 2 Scape and pedicel of antenna of (A) male and (B) female M. sexmaculatus, showing sensilla chaetica (Sc1-Sc4), Ca (campaniformia), Böhm Bristles (BB1), basiconica (Ba1) and Placoidea (PI).

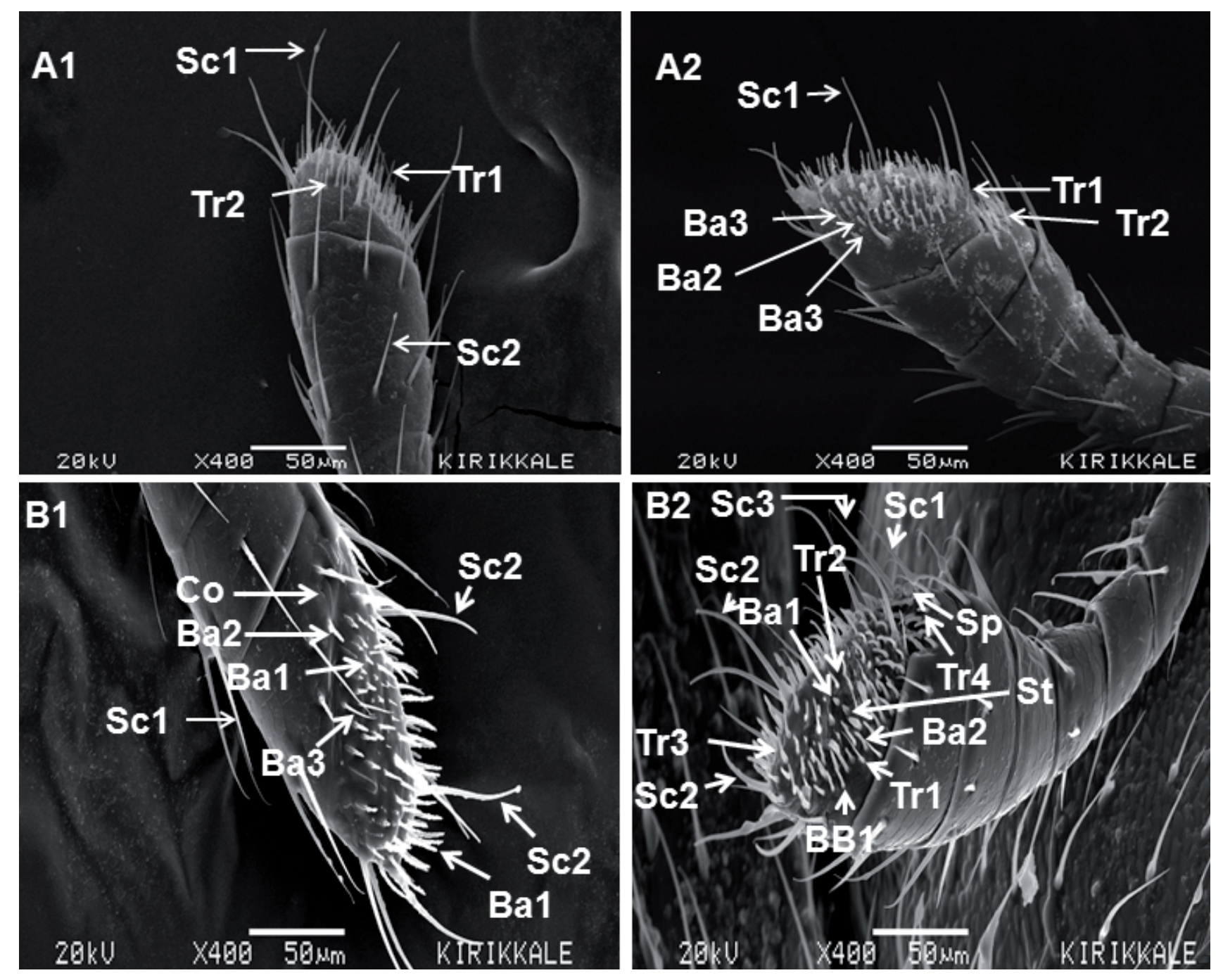

Fig. 3 Flagellomeres $F 8$ and $F 9$ of the antennae of male $(A 1, A 2)$ and female $(B 1, B 2) M$. sexmaculatus showing different sensilla: chaetica (Sc), trichoidea (Tr), basiconica (Ba), sporangium (Sp), coeloconica (Co), styloconica (St), Böhm bristles (BB1). 

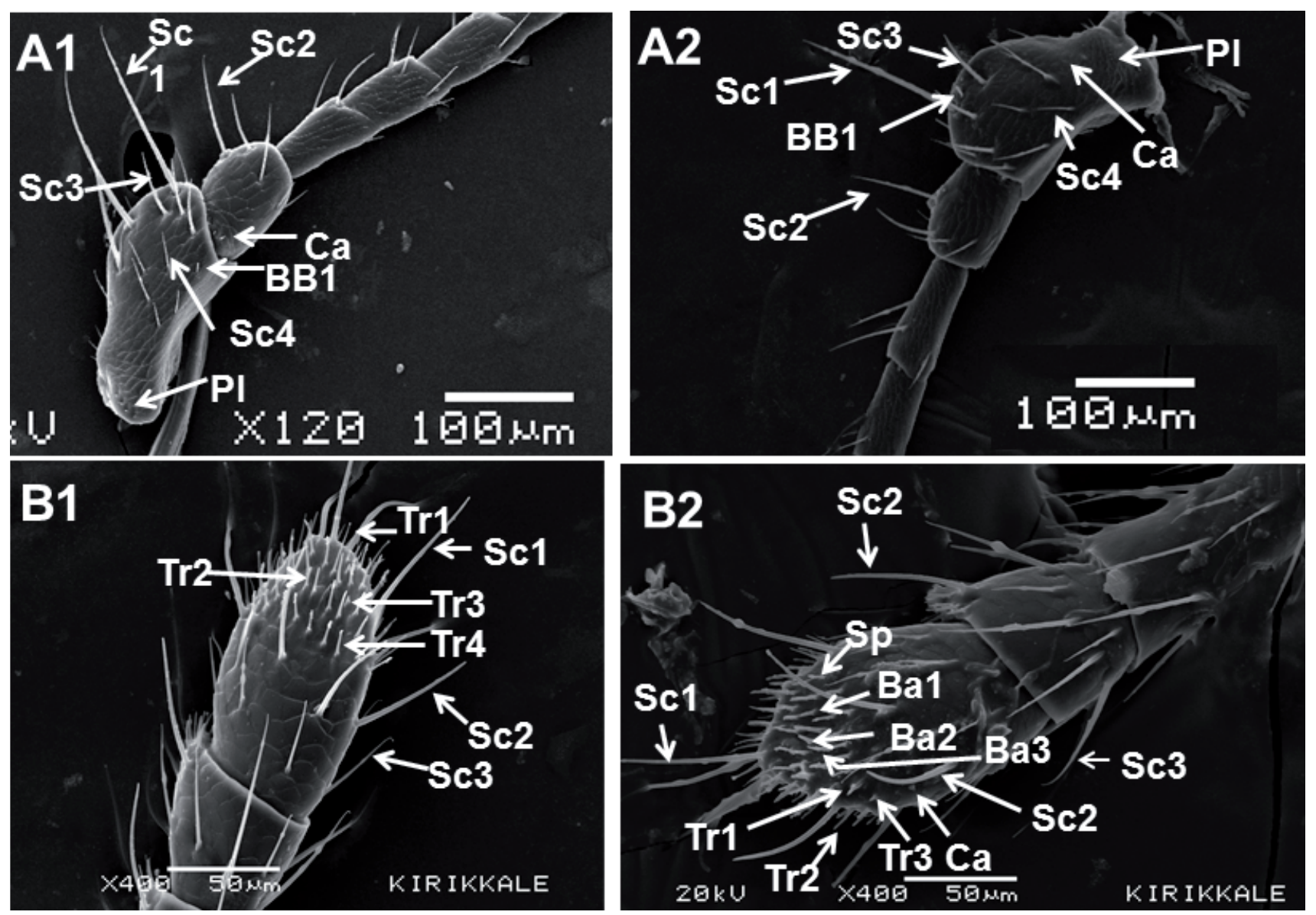

Fig. 4 Scape and pedicel of (A1) Male and (A2) Female P. dissecta showing sensilla: chaetica (Sc), placoidea (PI), campaniformia (Ca) and Böhm bristles (BB). Terminal flagellomere F9 of (B1) Male and (B2) Female P. dissecta showing sensilla: trichoidea (Tr), basiconica (Ba), campaniformia (Ca), sporangium (Sp) and chaetica (Sc).

of F9 in males, and four Ba3 $(15-18 \mu \mathrm{m})$, numerous Ba1 (3-6 $\mu \mathrm{m})$ and $\mathrm{Ba} 2(10-15 \mu \mathrm{m})$ on F9 in females (Fig. 3). In female $P$. dissecta there are three Bal $(4-6 \mu \mathrm{m})$, five $\mathrm{Ba} 3(10-15 \mu \mathrm{m})$ and numerous Ba2 on F9 (Fig. 4B1, B2).

\section{Böhm bristles (BB)}

$\mathrm{BB}$ are small thorn-like smooth walled sensilla embedded in a circular pocket on the scape and pedicel of antennae. There are two subtypes of BB: BB1 and BB2. $\mathrm{BB} 1$ has a blunt tip and is shorter than $\mathrm{Ba}$ and thinner than Tr. BB2 has a ' $V$ ' shaped branched tip, which is blunt and short. One BB1 is present on the scapes of males and females of $P$. dissecta (Fig. 4A1, A2) and one BB1 (4-10 $\mu \mathrm{m})$ on the scape of male M. sexmaculatus, but not on that of females (Fig. 2A, B).

\section{Sensilla campaniformia (Ca)}

They are small dome shaped structures in sockets and are present on the pedicel of male and female $M$. sexmaculatus (Fig. 2A, B). They are also present on the scape (Fig. 5A2) and $F 9$ of female P. dissecta (Fig. 4B2).

\section{Sensilla placoidea (PI)}

They are elliptical sunken plates. There are three Pl present on the scapes of both the sexes of M. sexmaculatus (Fig. 2A, B) and four and two present on the proximal part of the scape in male and female $P$. dissecta, respectively (Fig. 4A1, A2).

\section{Sensilla sporangium (Sp)}

They are a pole-shaped and resemble sporangia, and have an apical protuberance. They are only present on $F 9$ of females. There are three $(7-18 \mu \mathrm{m})$ and four (10-25 $\mu \mathrm{m}$ ), respectively, on F9 of P. dissecta (Fig. 4B2) and M. sexmaculatus (Fig. 3B2).

\section{Sensilla coeloconica (Co)}

They are small pits that resemble pores. One Co is present on F8 of male M. sexmaculatus (Fig. 3B1).

\section{Sensilla styloconica (St)}

They are smooth cylindrical structures with blunt tips and are present on the apical region of F9. There is one (5-8 $\mu \mathrm{m})$ on the F9 of females of both M. sexmaculatus and P. dissecta (Fig. 3B2).

\section{Discussion}

The antennae of females of $M$. sexmaculatus and $P$. dissecta are longer than those of the males, as is reported for Coccinella septempunctata L. (Srivastava and Omkar 
2003). Adult female ladybirds are bigger, therefore, their appendages, like antennae, are also comparatively longer than those of males. Despite being smaller, the length of the antennae in $P$. dissecta are significantly longer than those of $M$. sexmaculatus. This difference was mainly due to length of $F 9$ flagellomere, which is almost three times longer in $P$. dissecta than in M. sexmaculatus. Even bigger ladybirds, like $H$. axyridis, have similar sized antenna (Chi et al. 2009).

Despite the morphological similarities in the shape, position and number of the antennal segments of the ladybirds studied with those of other species: C. septempunctata L. (Srivastava and Omkar 2003), Harmonia axyridis (Pallas) (Park et al. 2001) and Cryptolaemus montrouzieri (Mulsant) (Ping et al. 2013), there are subtle differences in the sizes of a few of the antennal segments. For instance, the size of the ninth flagellomere is significantly different from that of other flagellomeres in both male and female $P$. dissecta, which results in a great increase in the length of their antennae. The ninth flagellomere, however, is similar in size to other flagellomeres in M. sexmaculatus. Thus, the greater antennal length in $P$. dissecta is mainly due to a longer ninth flagellomere.

There are nine types of antennal sensilla in $M$. sexmaculatus and $P$. dissecta compared to five in Semiadalia undecimnotata Schn. (Jourdan et al. 1995), seven in H. axyridis (Chi et al. 2009) and C. montrouzieri (Ping et al. 2013) and eight in C. septempunctata (Srivastava and Omkar 2003). Sc1 is the longest sensillum and its presence on all parts of an antenna indicates its importance in mechanoreception (Broeckling and Salom 2003). Sc1 are significantly longer on $F 8$ of male antenna than that of the female in both species of ladybird, which might indicate it has secondary role in mate-recognition. Males of $P$. dissecta (Omkar and Pervez 2005) and $H$. axyridis (Obata 1987) examine female ladybirds by touching their body and antennae with their antennae. Presence of a large number of sensilla chaetica on male antennae further strengthens its probable role in mate-recognition.

Numerous sensilla trichoidea are present on $F 9$ of both species of ladybird. These sensilla are also probably involved in mate-recognition, as the F9 of male ladybirds touch adult female ladybirds during courtship behaviour (Obata 1987; Omkar and Pervez 2005). Brożek and Chłond (2010) suggest that sensilla trichoidea are mechano-sensory and Chi et al. (2009) indicate that in the aggregative behaviour of $H$. axyridis they may act as pheromone receptors. Basiconica are the third-most abundant and conspicuous sensilla on the antennae of the two ladybirds studied. The presence of numerous Ba on the ninth flagellomere indicates a probable role in the chemoreception of female sex-pheromones. Thus, these sensilla might be involved in searching and recognition of mates. The large number of these sensilla on male antennae is in accord with Jourdan et al. (1995), who report a large number of these sensilla on the antenna of male $S$. undecimnotata. Further, Zhang et al. (2011) report large numbers of sensilla basiconica on the antennae of males of the longicorn beetles Leptura arcuata Panzer and Leptura aethiops Poda (Coleoptera: Cerambycidae) and suggest they might have a role in the reception of sex-pheromones. Sensilla basiconica were initially thought to be thermo- and hygro-sensitive receptors (Steinbrecht 1989; Bartlet et al. 1999). However, they may also be chemoreceptors (Hu et al. 2009; Zheng et al. 2014; Yi et al. 2016). There are a few subtypes of sensillum basiconica, which vary in shape and size, which are present on $F 9$ of all ladybirds (Jourdan et al. 1995; Srivastava and Omkar 2003; Chi et al. 2009; Ping et al. 2013).

There are Böhm bristles on the scapes of male and female antennae of both species. In other insects these sensilla are usually on the scape and pedicel of antennae (Chi et al. 2009; Wei et al. 2015) and thought to be proprioceptors i.e. they perceive the movement and position of antenna (Ochieng et al. 2000; Onagbola and Fadamiro 2008). Böhm bristles sense mechanical stimulations and may induce cushioning action and control the speed of movement of antennae (Wei et al. 2015). These sensilla are named after L. K. Böhm (1911), who first described them in the order Lepidoptera. In the ladybirds studied, there was no sexual dimorphism in terms of the number, length or position of $\mathrm{BB}$.

There are only a few sensilla campaniformia on the F9 of male and female ladybirds. They are proprio-receptors that responds to stresses in the cuticle (Meng and Qin 2017), but may also have a gustatory function (Ochieng et al. 2000). Sensilla sporangium are present only on $F 9$ of females of both species of ladybirds. Sensillum ampullacea are only present on the $F 9$ of the antennae of males of $P$. dissecta and are thought to detect $\mathrm{CO}_{2}$ concentration (Kleineidam et al. 2000). Sensillum coeloconica are present on $F 9$ flagellomere of male $M$. sexmaculatus and are known to be thermo-receptors (Ruchty et al. 2009). Sensilla placoidea are more abundant on male antennae, which indicates they may have a role in courtship behaviour initiated by female pheromones (Yee 2014; Song et al. 2017). Thus, P. dissecta possibly benefits by having comparatively longer antenna and more sensilla basiconica than other coexisting ladybirds. This is the first report of an abundance of basiconica on their antennae other than those on F9 and the first study on the antennal sensilla of these two species of ladybirds. However, the exact role of these sensilla will only be revealed by further morphological and physiological investigations.

\section{Acknowledgements}

AP is thankful to Science and Engineering Research Board, Department of Science and Technology, New Delhi for funding this research (EMR/2016/006296). 


\section{REFERENCES}

Bartlet E, Romani R, Williams IH, Isidoro N (1999) Functional anatomy of sensory structures on the antennae of Psylliodes chrysocephala L. (Coleoptera: Chrysomelidae). Int J Insect Morphol Embryol 28: 291-300.

Böhm LK (1911) Die antennale Sinnesorgane der Lepidopteren. Arbeiten aus dem Zoologischen Instituten der Universität Wien und der Zoologischen Station in Triest 14: 219-246.

Broeckling CD, Salom SM (2003) Antennal morphology of two specialist predators of Hemlock woolly adelgid, Adelges tsugae Annand (Homoptera: Adelgidae). Ann Ent Soc Amer 96: $153-160$

Brożek J, Chłond D (2010) Morphology, arrangement and classification of sensilla on the apical segment of labium in Peiratinae (Hemiptera: Heteroptera: Reduviidae). Zootaxa 2476: 39-52.

Chaudhary DD, Mishra G, Omkar (2016) Last male wins the egg fertilization fight: A case study in ladybird, Menochilus sexmaculatus. Behavioural Processes 131: 1-8.

Chi D, Wang GL, Liu JW, Wu QY, Zhu YP (2009) Antennal Morphology and Sensilla of Asian Multicolored Ladybird Beetles, Harmonia axyridis Pallas (Coleoptera: Coccinellidae). Ent News 120: 137-152.

Dubey A, Saxena S, Mishra G (2018) Mating experience influences mate choice and reproductive output in an aphidophagous ladybird, Menochilus sexmaculatus. Anim Biol 68: 247-263.

Hodek I, Evans EW (2012) Food relationship. In: Hodek I., van Emden HF, Honek A (eds) Ecology and behaviour of ladybird beetles (Coccinellidae), Wiley-Blackwell, UK.

Hu F, Zhang G-N, Wang J-J (2009) Scanning electron microscopy studies of antennal sensilla of bruchid beetles, Callosobruchus chinensis (L.) and Callosobruchus maculatus (F.) (Coleoptera: Bruchidae). Micron 40: 320-326.

Jourdan H, Barbier R, Bernard J, Ferran A (1995) Antennal sensilla and sexual dimorphism of the adult ladybird beetle Semiadalia undecimnotata Schn. (Coleoptera: Coccinellidae). Int J Ins Morphol Embryol 24: 307-322.

Kleineidam C, Romani R, Tautz J, Isidoro N (2000) Ultrastructure and physiology of the $\mathrm{CO}_{2}$ sensillum ampullaceum in the leaf-cutting ant Atta sexdens. Arthropod Struct Dev 29: 43-55.

Meng Y, Qin D (2017) Structure and sensilla of the antennae and mouthparts of Loxocephala perpunctata Jacobi (Hemiptera: Fulgomorpha: Eurybrachidae). Acta Zool 00: 1-18. doi: 10.1111/azo.12239.

Obata S (1987) Mating behavior and sperm transfer in the ladybird beetle, Harmonia axyridis Pallas: Coleoptera: Coccinellidae. Appl Entomol Zool 22: 434-442.

Ochieng SA, Park KC, Zhu JW, Baker TC (2000) Functional morphology of antennal chemoreceptors of the parasitoid Microplitis croceipes (Hymenoptera: Braconidae). Arthropod Struct Dev 29: 231-240.

Omkar, Pervez A (2000) Sexual dimorphism in Propylea dissecta (Mulsant), (Coccinellidae: Coleoptera). J Aphidol 14: 139140.

Omkar, Pervez A (2004) Predaceous coccinellids in India: Predator-prey catalogue. Orient Insects 38: 27-61.

Omkar, Pervez A (2005) Mating behavior of an aphidophagous ladybird beetle, Propylea dissecta (Mulsant). Insect Sci 12: 37-44.

Omkar, Pervez A (2008) Antennal sensilla of an aphidophagous ladybird, Propylea dissecta. J Appl Biosci 34: 168-171.

Omkar, Pervez A (2011) Ecology of an aphidophagous ladybird Propylea: A Review. J Asia Pacific Entomol 14: 357-365.
Omkar, Pervez A (2016) Ladybird beetles, In: Ecofriendly Pest Management for Food Security (OMKAR Ed). Academic Press, London, UK, pp 281-310.

Onagbola EO, Fadamiro HY (2008) Scanning electron microscopy studies of antennal sensilla of Pteromalus cerealellae (Hymenoptera: Pteromalidae). Micron 39: 526-535.

Park SJ, Oh HW, Youn YN, Park HY (2001) Structure of antennal sensilla on the adult Asian ladybird, Harmonia axyridis Pallas (Coleoptera: Coccinellidae). Korean J Electron Microscopy 31: 91-99.

Pervez A, Kumar R (2017) Preference of the aphidophagous ladybird, Propylea dissecta for two species of aphids reared on toxic host plants. Eur J Environ Sci 7: 130-134.

Pervez A, Omkar, Harsur MM (2020) Coccinellids on Crops: Nature's Gift for Farmers. In: Akshay Kumar Chakravarty (Ed.) Innovative Pest Management Approaches for the 21st Century: Harnessing Automated Unmanned Technologies. Springer International Publisher, Singapore. pp 429-460.

Pervez A, Omkar, Richmond A (2004) The influence of age on the reproductive performance of a predatory ladybird, Propylea dissecta. J Insect Sci 4: 1-8.

Pervez A, Singh S (2013) Mating patterns in the aphidophagous Ladybird, Hippodamia variegata, depend on body size. Eur J Environ Sci 3: 109-112.

Pervez A, Singh, PP, Bozdogan H (2018) Ecological perspective of the diversity of functional responses. Eur J Environ Sci 8: 5-9.

Pervez A, Yadav M (2018) Foraging behaviour of predaceous ladybird beetles: a review. Eur J Environ Sci 8: 10-16.

Ping L, Yu-Hong Z, Hong-Sheng W, Jia-Qin X, Cong-Shuang D, Hong P (2013) Antennal sensilla of Cryptolaemus montrouzieri Mulsant (Coleoptera: Coccinellidae). J Environ Entomol 35: 478-485.

Poorani J (2002) An annotated checklist of the Coccinellidae (Coleoptera) (excluding Epilachninae) of the Indian sub-region. Oriental Insects 36: 307-383.

Ruchty M, Romani R, Kuebler LS, Ruschioni S, Roces F, Isidoro N, Kleineidam CJ (2009) The thermo-sensitive sensilla coeloconica of leafcutting ants (Atta vollenweideri). Arthropod Struct Dev 38: 195-205.

Song LM, Wang XM, Huang JP, Zhu F, Jiang X, Zhang SG, Ban LP (2017) Ultrastructure and morphology of antennal sensilla of the adult diving beetle Cybister japonicus Sharp. PLoS ONE 12: e0174643.https://doi.org/10.1371/journal. pone .0174643

Srivastava S, Omkar (2003) Scanning Electron Microscopy of antennae of Coccinella septempunctata (Coccinellidae: Coleoptera). Ent Sinica 10: 271-279.

Steinbrecht RA (1989) The fine structure of thermo-/hygrosensitive sensilla in the silkmoth Bombyx mori: Receptor membrane substructure and sensory cell contacts. Cell Tissue Res 255: 49-57.

Wei C, Ren B, Chen X, Zhou X, Wang W, Wang Z (2015) Scanning electron microscope observations on the antennal sensilla of two stored grain pests Trogoderma granarium and Trogoderma variabile (Coleoptera: Dermestidae). Fla Entomol 98: $140-148$.

Yee DA (2014) An Introduction to the Dytiscidae: Their Diversity, Historical Importance, Cultural Significance, and Other Musings. Ecology, Systematics, and the Natural History of Predaceous Diving Beetles (Coleoptera: Dytiscidae). Berlin: Springer Netherlands.

Yi Z, Liu D, Cui X, Shang Z (2016) Morphology and Ultrastructure of Antennal Sensilla in Male and Female Agrilus mali (Coleoptera: Buprestidae). J Insect Sci 16: 86: 1-10. 
Zhang J, Guan L, Ren B (2011) Fine Structure and Distribution of Antennal Sensilla of Longicorn Beetles Leptura arcuata and Leptura aethiops (Coleoptera: Cerambycidae). Ann Ent Soc Amer 104: 778-787.
Zheng H, Liu H, Guo S, Yan Y, Zong S, Zhang J (2014) Scanning electron microscopy study of the antennal sensilla of Catocala remissa. Bull Insectol 67: 63-71. 